\title{
Learning How to Learn: A Six Point Model for Increasing Student Engagement
}

\author{
Gail Caruth $^{*}$ \\ Adjunct Faculty, Department of Educational Leadership at Texas A\&M University- \\ Commerce, USA
}

\begin{tabular}{l}
\hline \hline Article history \\
\hline Received: \\
11.06 .2014 \\
Received in revised form: \\
23.06 .2014 \\
Accepted: \\
24.06 .2014 \\
Key words: \\
\hline Andragogy, pedagogy, adult \\
learning, student engagement, \\
student retention, student \\
success
\end{tabular}

Students in higher education are being taught pedagogically. Moreover, pedagogy has long persisted as the basis for the entire educational system. Education is, however, discovering that adults learn differently than children learn even though they have been taught as children were taught. Students tend to behave dependently when they are in a structured, pedagogical educational setting. This dependent behavior may be because these learners do not know how to learn, they only know how to be taught. In pedagogy, the instructor is in charge and held entirely responsible for all learning: what is to be taught, how it is to be taught, when it is to be taught, how it is to be measured, etc. Adult students need to be taught how to learn in order to become life-long, autonomous learners. Research demonstrates that adult students being taught andragogically become engaged in the learning process. They are ready for learning, learn more, experience more meaningful learning, and enjoy learning. This paper presents a six point plan for promoting engagement for students in the college classroom: create a safe environment for learning; ask students what they need to know; explain why students are learning certain concepts, theories, skills, etc.; provide real-life learning opportunities; offer opportunities for collegial collaboration; and have students evaluate their own learning. Collaboration between educators on the six points will also increase the likelihood of engaging students. Student engagement leads to improved retention and ultimately to student success. 


\section{Introduction}

Getting a college education pays over a million dollars more over a lifetime as opposed to not getting a college degree. Even though evidence demonstrates many additional personal benefits for earning a college degree (Tinto, 2012), the graduation rates for students seeking bachelor's or equivalent degrees equalled $38.6 \%$ in four years, $54.3 \%$ in five years, and $58.7 \%$ in six years in United Sates colleges and universities. The colleges and universities included in these rates are Title IV institutions, those with a written agreement with the Secretary of Education that allows the institution to participate in any of the Title IV federal student financial assistance programs (U.S. Department of Education, n.d.). If higher education is to increase student graduate rates, the focus must be on student engagement in the classroom. Student engagement leads to student retention and student success (Tinto, 2012). Vincent Tinto (2012), recognized for his work in the area of student success stated that "The classroom is the building block upon which student retention is build and the pivot around which institutional action for student retention must be organized" (p. 124). Furthermore, $\mathrm{Hu}$ and Wolniak (2013) maintained that social and academic engagement resulted in different effects on career earnings. Males on average, for example, were more engaged academically than females and earned higher salaries.

Malcolm Knowles received the Delbert Clark Award from West Georgia College In 1967. He was an educator of education at Boston University and a general consultant in adult education. The Delbert Clark Award was highly regarded as a national honor in the field of adult education. Knowles, credited with giving renewed meaning to adult education, maintained during his address at the awards banquet that for society to endure continuous learning into adulthood was necessary (Knowles, 1968).

Andragogy, as introduced by Knowles, was the science of teaching adult learners that focused on adults' characteristics of learning. The word andragogy was derived from the Greek word andros, which means "man" or "grownups" (Knowles, 1968, p. 351) or agogus meaning "leader of" (Knowles, Holton, \& Swanson, 2011, pp. 59-60), which translates to "the art and science of helping adults learn" (Knowles, 1984, p. 6). As a result of this focus on the characteristics of adult learners, adults should be taught andragogically (Beaman, 1998; Chan, 2010; Clemente, 2010; Clerk, 2012; Forrest \& Peterson, 2006; Hadley, 1975; Hughes \& Berry, 2011; Kiener, 2010; Knight, 1999; Knowles et al., 2011; Martell, 2011; Tatum, 2010; Taylor, 2010; Taylor \& Ruetzler, 2010; Yow, 2010; Zhang, 2009) to facilitate effectively learning.

\section{Understanding Pedagogy and Andragogy}

Schools for children were established in Europe to groom young boys for the priesthood during the early 7th century. Educators were accountable for teaching the values and ways of the church. This teaching became known as pedagogy, a word that is derived from the stem "pediatrics" from the Greek word paeda which means "child" (Knowles, 1968, p. 351). Ever since the $7^{\text {th }}$ century, pedagogy has endured as the foundation for all education (Knowles, 1990). As such, books on adult education reference the statement "the pedagogy of adult education" still today (Knowles, 1976, p. 37).

Knowles alleged that education was however, experiencing a transition and realized that adults learn in another way than children learn in spite of being educated as children were educated. Knowles further alleged that the curriculum for adults was distinct from the curriculum for children (1968). 
Knowles made one important distinction between a pedagog and an andragog:

An ideological pedagog would want to keep me dependent on a teacher, whereas a true andragog would want to do everything possible to provide me with whatever foundational content I would need and then encourage me to take increasing initiative in the process of further inquiry (as cited in Levitt, 1979, p. 53).

According to Knowles (1984), students are inclined to act dependently when in a more structured educational setting. This dependency might be due to the idea that these learners do not know how to learn and only know how to be taught. In pedagogy, the teacher is in control and regarded as totally accountable for all learning: what is to be taught, how it is to be taught, when it is to be taught, how it is to be measured, etc. Adult students need to be taught how to learn in order to become continuous, autonomous learners. The main purpose of education claimed Knowles, is to attain the capacity to inquire and to become life-long learners.

Teaching college and university students andragogcially in the classrooms is not done in higher education (Beder \& Darkenwald, 1982; Brookfield, 2006; Gorham, 1985; Harper \& Ross, 2011; Knowles, 1968; Knowles, 1976; Hadley, 1975; J. Henschke, personal communication, February 2, 2012; Rose, 2000) in spite of being encouraged to teach adult students andragogically (Anderson, 2007; Beaman, 1998; Chan, 2010; Clerk, 2012; Finn, 2011; Hadley, 1975; Hughes \& Berry, 2011; Minter, 2011: Kiener, 2010; Knight, 1999; Ritt, 2008; Tannehill, 2009; Tatum, 2010; Taylor \& Kroth, 2009; Taylor \& Ruetzler, 2010; Yow, 2010). Consequently, higher education is not fulfilling its purpose to teach adult learners effectively (Brookfield, 2006; Harper \& Ross, 2011; Knowles, 1968; Rose, 2000).

Dr. John Henschke, a student and colleague of Knowles (Henschke, 2011b) and chair of the Andragogy Doctoral Emphasis Specialty at Lindenwood University, delivered the eulogy at Knowles' memorial service (Henschke, Winter 97-98). Henschke alleged that hardly any of the andragogical assumptions are being utilized in today's colleges and universities. In fact, much of what is delivered in classrooms is not consistent with the principles of andragogy. Most attempts to employ andragogical principles are incompatible with the assumptions of andragogy. What is being taught does not meet the needs of the learners. Moreover, what is being taught favors higher education, is more in the nature of adult education, and is not in the nature adult learning (J. Henschke, personal communication, February 2, 2012).

A key distinction between pedagogy and andragogy is the impression one has of oneself and the acknowledgment of the characteristics of the learner. For example, children see themselves as being dependent on adults until they begin to make their own decisions for themselves and experience the fulfillment of making those independent decisions. As youth grow into adulthood, they view themselves as independent and self-directed. Andragogy is based on adults' need to be regarded as self-directed adults (Knowles, 1968).

\section{Knowles' Andragogical Model}

Before addressing andragogy and Knowles' Andragogical Model (Knowles et al., 2011, p. 63) it might be helpful to first reflect on the term adult. The term adult can be defined as, (a) when one becomes biologically responsible--the point at which one is able to reproduce; (b) when one becomes legally responsible--the point at which one is able to vote; (c) when one becomes socially responsible--the point at which one can work and marry; or (d) when one becomes psychologically responsible--the point at which one begins to feel 
responsible for his or her own life. Psychological independence is significant in adult learning. This sense of independence is gaining self-awareness and self-directedness. This sense of independence is something that develops over time as children mature into adulthood. Research conducted on psychological characteristics of adulthood has centered on internal processes and not the chronological age of adults. In other words, the focus has been more about an ordered hierarchy of development (Merriam, Caffarella, \& Baumgartner, (2007).

Knowles' Andragogical Model originally focused on four learning principles which over time developed to six assumptions (Laird, Naquin, \& Holton, 2003; Knowles et al., 2011; Merriam et al., 2007). The six assumptions, different from theories of pedagogical methods, include adults' need to know, self-concept, prior learning experience, readiness to learn, learning orientation, and motivation to learn.

\section{Adults Need to Know}

Before learning can occur, adults have a desire to know why they need to know a particular skill, ability, knowledge, etc. Accordingly, educators are encouraged to help learners understand why they "need to know" what is being taught. Helping adults understand why they "need to know" something being taught in the classroom results in learning and strengthens the value of learning. This conscience awareness of the value of learning guides learners in realizing for themselves the disparity between what they know and what they should know (Knowles et al., 2011).

\section{Self-Concept}

Once adults accept the accountability for their decisions and actions, they have an internal emotional need to be viewed and acknowledge as able to be self-directed. This selfconcept of being independent, once understood can introduce challenges for educators. For example, adult learners resist and resent teachers imposing the perception that "learner equals dependent" (p. 65). This perception of dependency and teachers' handling adult learners as dependent creates internal conflict for adults. A predictable reaction to this conflict is to escape, which may account for the high dropout rates in higher education (Knowles et al., 2011).

\section{Prior Learning Experience}

Educators are encouraged to remember that adults develop their identities from past experiences, "it is who they are" (Knowles et al., 2011, p. 66). To devalue their experiences would be akin to devaluing them. Personal experiences of adult learners, therefore, might have an effect on education. Collaborative activities such as group discussions, problem solving assignments, simulation exercises, and case studies where peers are helping peers can be effective teaching methods.

\section{Readiness to Learn}

Adults are ready to learn what they need to know and do as the need arises in their personal lives. Timing is critical as a result. To invest time in the classroom on learning skills that adults do not think they need to know or can make use of is considered pointless. Learning is more effective if it corresponds with a need to know (Knowles et al., 2011). 


\section{Learning Orientation}

When it comes to learning adults are problem-centered and learn best in an environment of realistic problems. The focus of problem-centered learning is to facilitate effective problem-solving skills, self-directed learning, collaboration skills, flexibility, and intrinsic motivation. Through collaborative activities and discussions, adults learn to recognize what they already know, what they need to know, where to access new information, how to resolve problems, etc. (Knowles et al., 2011).

Efforts to reduce illiteracy, for example, have been disappointing. The words that students were learning were not the words they used daily. As a result, they were considered pointless and learning them was a waste of time the minds of the learners. However, Knowles et al. (2011) investigated courses offered through extension programs during the evenings that corresponded to courses offered to students earlier in the day. The day courses were Composition I, Composition II, and Composition III and the corresponding evening courses were Writing Better Business Letters, Writing for Pleasure and Profit, and Improving Your Professional Communications. Knowles discovered that students attending day classes memorized the grammar rules while students attending evening classes began writing better business letters and improving their grammar skills.

\section{Motivation to Learn}

Adults are motivated to learn externally and internally; however, educational barriers can have a negative effect on motivation for learning (Knowles et al., 2011). Adults are ultimately motivated to learn internally and more effective learning occurs when personal goals, interests, attitudes, and beliefs come from learners rather than the instructor. Thus, the learner is the self-motivator or internal teacher (Knowles, 1975).

\section{Process Design Steps: Strategies for Teaching Andragogically}

Knowles suggested approaches for adult learning (Merriam et al., 2007). These approaches can be referred to as eight "process design steps" for creating effective learning. The eight steps are:

(1) Prepare students by providing information, encouraging participation, developing realistic results, and thinking about course content.

(2) Create a climate that is beneficial for students to learn by demonstrating trust, support, collaboration, ability to relax, respect for one another, and pertinent information.

(3) Involve students in planning by shared planning between students and educator.

(4) Involve students in identifying learning requirements and assessments between students and educator.

(5) Involve students in developing learning objectives by mutual negotiation between students and educator.

(6) Involve students in establishing learning plans by joint planning between students and educator through learning contracts and learning activities according to the readiness of students.

(7) Facilitate students in completing learning plans by experiential opportunities, inquiry projects that provide opportunities to use prior knowledge to investigate an issue, and independent study.

(8) Involve students in the evaluation of their learning experiences by mutual planning after assessment information is collected. 
In essence, encouraging mutuality and reciprocity in the process design steps encourages student ownership, which is often considered motivational. Once adults feel ownership for their own learning, learning will take place (Laird et al., 2003).

Andragogy in higher education has been slow to come about. Colleges and universities do not teach andragogy to aspiring and promising educators (Brookfield, 2006). There is little empirical research that tests the validity on how much learning is actually gained in spite of andragogy being the recognized method for adult learning, (Merriam et al., 2007; StagnaroGreen, 2004). Andragogy appears to be making its way gradually into American higher education. Furthermore, evidence indicates a developing use of andragogical assumptions in post-secondary education (Knowles et al., 2011).

\section{Research on Andragogy}

In spite of andragogy being considered the principal method of adult learning for over 40 years, there has been minimal empirical research completed on Knowles assumptions (Merriam et al., 2007). Henschke (2011a) alleged that there are 330 published documents on andragogy by different authors. Research on adult education has been not been about the teaching of adults in higher education but in the practice of adult learning in business and industry. What research there is has not been translated into higher education practice and educators are not trained in adult education (Brookfield, 2006; Rose, 2000).

Ann Hartree (1984), a critic of Knowles' assumptions of andragogy, challenged the lack of clarity and general ambiguity. Hartree claimed that the link between adult and child learners is blurred and the six assumptions are nebulous. She also claimed that andragogy's foundation on man's "existence" (p. 208) explains the lack of clarity of whether andragogy is about adult learning or about teaching adults.

It bears mentioning that Knowles (1976) himself acknowledged the need for empirical research on andragogy. He proposed that "mutual inquiry" (p. 15) was needed to continue to define the field of adult education. He further suggested that this mutual relationship of inquiry was "pioneering" (p. 16). It requires cooperation, patience, and collaboration on the part of researchers and that those who want "pat answers, neat categories, and proved theories will be uncomfortable in the climate" (p. 16) of andragogy and adult education as it is.

Self-directed learning (SDL) has created the largest amount of attention, debate, and empirical research within the field of adult education (Knowles et al., 2011; Merriam et al., 2007). Knowles (1975) defined SDL as adults taking responsibility for defining their own learning needs and satisfying those needs. SDL occurs in collaboration with others such as teachers and peers. SDL requires an atmosphere of mutuality and reciprocity between self-directed learners and others. According to Zang (2009), this relationship of mutuality and reciprocity presents an opportunity and a challenge.

According to Henschke (2011a), conversations of andragogy in the future should surpass Knowles' model of andragogy to integrate global viewpoints in the field and bond with other adult learning theories. Continuous study will help to "establish andragogy as a scientific academic discipline" (p. 36). The discipline of adult learning will continue to be questioned. As the debates transpire progress is to be expected in the future research and practice in andragogy (Knowles et al., 2011).

A few examples demonstrating student engagement when adragogical principles are applied 
in higher education are presented below:

- Students at one university designed their own degree plans and as a result were better students, understood where learning was headed, experienced academic improvement, and derived pleasure from education (Harper \& Ross, 2011).

- Students attending the National Restaurant Association (NRA) Show hosted at four universities welcomed the opportunity to be active in defining their individual learning objectives in a learning contract that was integrated with specific requirements to enhance the educational experience (Taylor \& Ruetzler, 2010).

- Law students in Idaho claimed that they became more self-directed, were more receptive to the traditional customs of practicing law when educators applied course content to experiences, were aware of an increase in readiness, felt an orientation to learn, were more motivated to learn, and were more willing to go through the learning process when they were informed about what they would learn and the reasons for learning (Taylor, 2010, p. 185).

- Management education in higher education is more effective for students when using: role-playing because its use of experience gives weight to knowledge; problem-based learning because it allows adults to be self-directed; and service learning because it allows students to express their self-image as civilians in real community problems. Lectures can be an effective instructional method when educators ask students what they need to know because students will be more interested in listening to a lecture on creating a mission statement, for example, when they understand the importance of mission statements to organizations (Forrest \& Peterson, 2006).

- Law students felt that they learned more when experienced attorneys discussed practical experiences on the job (Taylor \& Kroth, 2009) during lectures.

- Martell (2011) compared the effectiveness of a lecture-based to a discussion-based teaching philosophy in adult bible fellowships (ABFs) in Akron, Ohio. The group that learned under the discussion-based method experienced greater learning, felt more confident with the teaching method, and thought that the discussions were the most memorable part of the lesson.

- According to Beder and Darkenwald (1982) data collected from 173 public school and college teachers indicated that accentuating responsive, learner-centered patterns and de-accentuating power and rules engaged learners.

- Hughes and Berry (2011) claimed that students should be provided opportunities to be involved in making decisions for their own learning methods instead of being handfed information. If this collaboration is initiated early in the process, students will appreciate having control of their learning and will demonstrate the value of education.

- Clemente (2010) found that the self-concept of learners moved from dependency to self-directing in multi-generational community college classrooms. As time progressed during the semester, students overcame anxiety, became more at ease with being students, took responsibility for managing their coursework, and found that students' readiness to learn reflected social constructivism, which suggests that students construct more meaning in knowledge gained from personal experience than from learning passively.

- Zhang (2009) claimed that learning is more meaningful if both the educator and the learner (a) shared the responsibility for the design of the learning goals and objectives, (b) interacted with other members of the class, (c) promoted reflection on experiences, 
(d) related new examples that made sense to the learner, (e) maintained self-directed learning, and (f) evaluated learning.

- Knight (1999) found that learning and confidence increased when learners are provided with hands-on computer learning opportunities. Allowing students to maintain control of the mouse and the computer keyboard for example, increased learning outcomes. Therefore, it is important that computer programs and manuals be easy to work with and to understand.

- Korr, Derwin, Greene, and Sokoloff, (2012) maintained that students compare learning something new to past experiences to establish new information, consider busy work offensive, separate new learning from their everyday lives, anticipate individualized feedback from educators as opposed to just receiving a grade, and are inspired by relevant problem-solving activities.

- Traditional grading methods need to change for college age students suggested Beaman (1998). Some alternative methods include peer evaluations, self-assessments, praiseworthy grading (pointing out successes rather than failures), and checklists for quality (measurements of the quality of an idea). Praiseworthy grading and checklists for quality provide instructor feedback in a more facilitative manner than with traditional grading approaches.

- Instructors can enhance learning by being available for questions and providing an environment that encourages questions free from criticism and disapproval (Knight, 1999).

- Once learning is internalized, the learner is ready to move on to the next learning experience. Therefore, it is important that educators communicate to learners the impact, method, and implementation of learning and understand that learners have different learning styles and preferences (Clerk, 2012).

In summary, the objective of learning is to permit learners to carry out their learning according to what that learning represents for them. Consequently, learners are learning how to learn. This practice of learning how to learn, over time, facilitates learners' ability to form their own awareness of their truths (Hadley, 1975). Learners begin to know themselves, their capabilities, and their aspirations. This knowledge is immensely important (Knowles, 1984).

Educators are encouraged therefore to instigate discussions with colleagues on teaching and sharing experiences. Unfortunately educators typically employ an assortment of learning theory and practice and may not be cognizant of what method of learning they practice in their classrooms. Educators' teaching methods center on their individual ideas of what is suitable without verifying whether research supports their teaching method (Minter, 2011).

Educators are also encouraged to take into account the needs of the student when designing the curriculum (Knight, 1999). It is necessary to consider that many students experience at least one educational barrier (responsibilities to family, responsibilities to work, responsibilities to community, self-concepts, unattainable opportunities, etc.) in their lifetime (Clerk, 2012; Finn, 2011; Ritt, 2008). As a result of these barriers, students are apt to leave post-secondary education without earning a degree (Clerk, 2012; Tannehill, 2009). For that reason, remembering how important an inviting educational environment (safe, successful, interesting, etc.) is will make up for the challenges and will enhance the likelihood of engaging students (Finn, 2011). According to Tinto (2012), removing barriers leads to success in higher education.

In conclusion, Wasley (2006) maintained that student engagement customarily falls under the 
responsibility of the college student affairs area. However, if the purpose for going to college is to obtain an education (Hutchins, 1938) and the purpose of getting an education is to encourage continuous learning (Knowles, 1984), then educators must engage the students in the classroom in order to retain them in colleges and universities (Tinto, 2012). Kuh (2006) claimed that student engagement has a positive effect on student retention. It is through the process of retaining students in higher education that these same students will become society's life-long learners of the future, thereby insuring the very survival of civilization (Knowles, 1968). By facilitating students' ability to learn how to learn rather than by learning how to be taught (Hadley, 1975), student engagement and retention can be accomplished avoiding any reactions to flee the classrooms (Knowles et al., 2011). This learning how to learn can be accomplished through the assumptions of the students' need to know, selfconcept, prior learning experience, readiness to learn, learning orientation, and motivation to learn (Knowles et al., 2011).

\section{Learning How to Learn: A Model for Student Engagement}
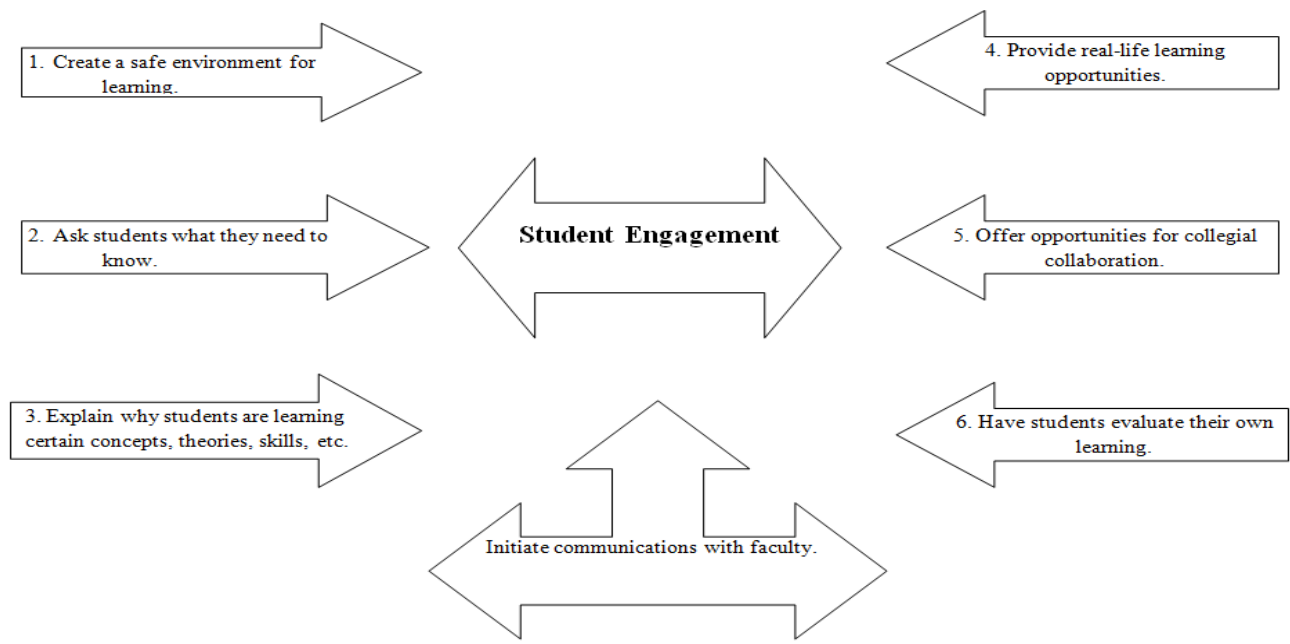

(1) Create a safe environment for learning. Provide an environment that encourages questions free from criticism that is safe, successful, interesting, etc. for students.

(2) Ask students what they need to know. Probe students about what they need to know because they will be more interested in classroom activities and learning is more effective if it coincides with a particular need to learn.

(3) Explain why students are learning certain concepts, theories, skills, etc. Help students learn about the value of learning to realize for themselves that there is a gap between where they are and where they should be. To invest time on learning something that they do not relate to or can make use of is considered pointless. Learning is more effective if it coincides with a particular need to learn

(4) Provide real-life learning opportunities. Establish a learning environment with realistic problems because adults are problem-centered when it comes to learning.

(5) Offer opportunities for collegial collaboration. Introduce group activities and discussions, problem solving assignments, simulation exercises, case studies, etc. in the classroom. Emphasis on peers helping peers on real-life problems enhances students' ability to identify what they already know, what they need to know, where to access new information, how to resolve problems, etc. 
(6) Have students evaluate their own learning. Share the responsibility for evaluating learning and designing learning goals and objectives that make sense to students. Help students to become self-directed learners.

Overall alignment of collaboration and cooperation in higher education is "key" (Tinto, 2012, p. 112) for student engagement that ultimately leads to student retention and success in higher education. From that one could assume a seventh point in the model and that is to initiate faculty communication with other faculty through formal and informal meetings sharing insights and experiences. Collaboration between educators on teaching and sharing experiences regarding the six points for engaging students will result in enhancing the likelihood of engaging students.

\section{References}

Anderson, J. M. (2007). A conceptual framework of a study in preferred learning styles: Pedagogy or andragogy (Unpublished doctoral dissertation). Spalding University, Louisville, Kentucky.

Beaman, R. (1998). The unquiet...even loud, andragogy! Alternative assessments for adult learners. Innovative Higher Education, 23, 47-59. doi:10.1023/A:1022920513341

Beder, H. W., \& Darkenwald, G. G. (1982). Differences between teaching adults and preadults: Some propositions and findings. Adult Education, 32(3), 142-155. doi:10.1177/074171368203200303

Brookfield, S. D. (2006). The skillful teacher: On technique, trust, and responsiveness in the classroom (2nd ed.). San Francisco, CA: Jossey-Bass.

Chan, S. (2010). Applications of andragogy in multi-disciplined teaching and learning. Journal of Adult Education, 39(2), 25-35.

Clemente, K. A. (2010). Experiences of adult students in multi-generational community college classrooms (Unpublished doctoral dissertation). Pennsylvania State University, University Park, PA.

Clerk, K. (2010). Student perception and success: How adult learners at a two-year technical institution perceive instruction and how their perceptions contribute to their overall academic success (Unpublished doctoral dissertation). Oakland University, Rochester, MI.

Finn, D. (2011). Principles of adult learning: An ESL context. Journal of Adult Education, 40, 34-39.

Forrest, S. P., \& Peterson, T. O. (2006). It's called andragogy. Academy of Management Learning \& Education, 5, 113-122.

Gorham, J. (1985). Differences between teaching adults and pre-adults: A closer look. Adult Education Quarterly, 35(4), 194-209. doi:10.1177/0001848185035004002

Green, G., \& Ballard, G. H. (2011). No substitute for experience: Transforming teacher preparation with experiential and adult learning practices. SRATE Journal, 20, 12-20.

Hadley, H. N. (1975). Development of an instrument to determine adult educator's orientation as andragogical and pedagogical (Unpublished doctoral dissertation). Boston University School of Education, Boston, MA.

Harper, L., \& Ross, J. (2011). An application of Knowles' theories of adult education to an undergraduate interdisciplinary studies degree program. The Journal of Continuing Higher Education, 59, 161-166. doi:10.1080/07377363.2011.614887

Hartree, A. (1984). Malcolm Knowles' theory of andragogy: A critique. International Journal of Lifelong Education, 3(3), 203-210. doi:10.1080/0260137840030304 
Henschke, J. (Winter 97-98). In memoriam: Malcolm S. Knowles. Adult Learning, 10451595, $9(2)$.

Henschke, J. A. (2011a). Considerations regarding the future of andragogy. Adult Learning, Futures Column, 22, 34-37. doi:10.1177/104515951102200109

Henschke, J. A. (2011b). Andragogy and its future, lifelong learning, my relationship with Malcolm S. Knowles, connection between learning and performance, and my commitment to andragogy. An Interview by Monica Fedeli from Italy with John A. Henschke. Fedeli, M. Ph.D, Interviewer and Translator. Journal of the Italian Association for Adult Education; Universita di Padova, Italy; Being Translated into Italian by Monica Fedeli; (In Press). Retrieved from: http://www.lindenwood.edu/education/andragogy/andragogyPublished.html

Hu, S. \& Wolniak, G. C. (2013). College student engagement and early career earnings: Differences by gender, race/ethnicity, and academic preparation. The Review of Higher Education, 36(2), 211-233.

Hughes, B. J., \& Berry, D. C. (2011). Self-directed learning and the millennial athletic training student. Athletic Training Education Journal, 6, 46-50.

Hutchins, R. M. (1938). Why Go To College? Saturday Evening Post, 210(30), 16.

Kiener, M. (2010). Examining college teaching: A coaching perspective. Rehabilitation Education, 24(1/2), 69-74.

Knight, K. J. (1999). Older adults and technology: A critical incident inquiry into learning experiences (Unpublished doctoral dissertation). Texas A\&M University-Commerce, Commerce, TX.

Knowles, M. S. (1968). Andragogy, not pedagogy. Adult Leadership, 16(10), 350-352, 386.

Knowles, M. S. (1975). Self-directed learning: A guide for learners and teachers. New York, NY: Association Press.

Knowles, M. S. (1976). The modern practice of adult education: Andragogy versus pedagogy. New York, NY: Association Press.

Knowles, M. S. (1984). Andragogy in action: Applying modern principles of adult learning. San Francisco, CA: Jossey-Bass.

Knowles, M. S. (1990). The adult learner: A neglected species (4th ed.). Houston, TX: Gulf.

Knowles, M. S., Holton, E. F., \& Swanson, R. A. (2011). The adult learner: The definitive classic in adult education and human resource development (7th ed.). Burlington, MA: Butterworth-Heinemann.

Korr, J., Derwin, E. B., Greene, K., \& Sokoloff, W. (2012). Transitioning an adult-serving university to a blended learning model. Journal of Continuing Higher Education, 60, 2-11. doi:10.1080/07377363.2012.649123

Kuh, G. D. (2006). Underrepresented students benefit most from "engagement." Retrieved from https://tle.wisc.edu/forum/underrepresented-studentsbenefit-most-engagement

Laird, D., Naquin, S. S., \& Holton, E. F. (2003). Approaches to training and development (3rd. ed.). New York, NY: Basic Books.

Levitt, L. (1979). Critique: Andragogy revisited II. Adult Education Quarterly, 30, 52-57. doi:10.1177/074171367903000104

Martell, J. (2011). Evaluating the effectiveness of andragogical teaching in adult bible fellowships at The Chapel, Akron, Ohio (Unpublished doctoral dissertation). The Southern Baptist Theological Seminary, Louisville, KY.

Merriam, S. B., Caffarella, R. S., \& Baumgartner, L. M. (2007). Learning in adulthood: A comprehensive guide (3rd ed.). San Francisco, CA: Jossey-Bass.

Minter, R. L. (2011). The learning theory jungle. Journal of College Teaching \& Learning, $8(6), 7-15$. 
Ritt, E. (2008). Redefining tradition: Adult learners and higher education. Adult Learning, 19(1/2), 12-16. doi:10.1177/104515950801900103

Rose, A. D. (2000). What is the state of adult education research today? Adult Learning, 11(4), 28-29. doi:10.1177/104515959901100410

Stagnaro-Green, A. (2004) Applying adult learning principles to medical education in the United States. Medical Teacher, 26, 79-85.

Tannehill, D. B. (2009). Andragogy: How do post-secondary institutions educate and service adult learners? (Unpublished doctoral dissertation). University of Pittsburgh, Pittsburgh, PA.

Tatum, C.G. (2010). An explanatory mixed methods inquiry into the academic experience of nontraditional community college students (Unpublished doctoral dissertation). Texas A\&M University-Commerce, Commerce, TX.

Taylor, B. F. (2010). Raising the bar: A qualitative study of adult learning theory and its effectiveness of law school education in preparing new graduates to begin the practice of law (Unpublished doctoral dissertation).University of Iowa, Iowa City, IA.

Taylor, B. F., \& Kroth, M. (2009). A single conversation with a wise man is better than ten years of study: A model for testing methodologies for pedagogy or andragogy [Electronic version]. Journal of the Scholarship of Teaching and Learning, 9(2), 4256.

Taylor, J., \& Ruetzler, T. (2010). A student-centered exploration of the national restaurant association show: Developing a course for academic credit. Journal of Culinary Science \& Technology, 8, 1-13. doi:10.1080/15428052.2010.486412

Tinto, V. (2012). Completing college rethinking institutional action. Chicago, IL: The University of Chicago Press.

U.S. Department of Education. (n.d.). National Center for Education Statistics, Integrated Postsecondary Education Data System (IPEDS). Spring 2012, Graduation Rates component (provisional data), table 121217. Extracted from the IPEDS Data Center http://nces.ed.gov/ipeds/datacenter/ on 12/14/2012; revised on 12/17/2012.

Yow, A. (2010). Employers' perceptions of basic technology skills needed for workplace preparation in adult basic education (Unpublished doctoral dissertation).Walden University School of Education, Minneapolis, MN.

Wasley, P. (2006). Underrepresented students benefit most from engagement. The Chronicle of Higher Education, 53, A39.

Zhang, J. (2009). Exploring education major focused adult learners' perspectives and practices of Web-based distance education in sixteen universities (Unpublished doctoral dissertation). New Mexico State University, Las Cruces, NM. 